\title{
Stump appendicitis: a challenging diagnosis
}

\author{
Suheil Artul ${ }_{1}^{1}$ Marron Daud ${ }^{2}$ Nabil Abboud ${ }^{3}$ Victor Assaff
}

1 Department of Radiology, EMMS Hospital, Bar Ilan University Faculty of Medicine, Nazareth, Israel ${ }^{2}$ Faculty of Medicine and Surgery, University of Pavia, Pavia, Italy

${ }^{3}$ Surgical Department, EMMS, Nazareth, Israel

\section{Correspondence to}

Suheil Artul,

suheil_artul@hotmail.com

Accepted 29 September 2014

\section{DESCRIPTION}

A 20-year-old male presented to our hospital after 2 days of low-grade fever, right lower abdominal pain and one episode of vomiting. The patient had undergone an appendectomy 2 months earlier. Physical examination showed abdominal rebound.

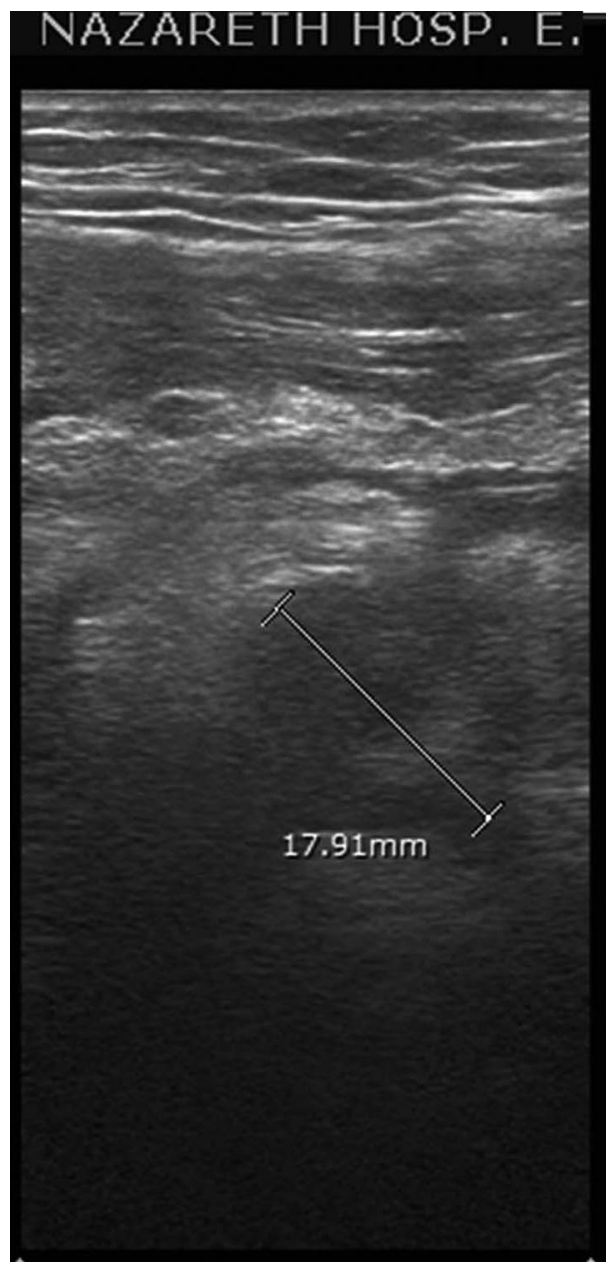

Figure 1 Ultrasound of right lower abdomen showing a thick appendix of $18 \mathrm{~mm}$.
Blood test revealed increased white cell count of 14000 (leucocytosis).

Ultrasound (US) of abdomen (figure 1) showed, surprisingly, an inflamed stump appendix of $18 \mathrm{~mm}$. CT confirmed the diagnosis of stump appendicitis (figure 2). The patient was treated at this time with intravenous antibiotics and had a good clinical outcome.

Stump appendicitis is a rare complication of postappendectomy with recurrence of 1 in 50000 cases. It is a challenging condition that is usually diagnosed and confirmed by means of imaging, especially by US and CT. Patients present with signs and symptoms mimicking those of appendicitis or acute abdomen. The time interval for onset of symptoms can range from 2 weeks to 2 years postappendectomy. ${ }^{1}$

Stump appendicitis usually occurs because of inadequate identification of the appendicular base due to severe local inflammation. It has been reported following open and laparoscopic appendectomy.

CT scan and US of the abdomen are both equally accurate for the diagnosis of stump appendicitis. Imaging findings may be similar to those seen in acute appendicitis. But usually because of rarity of this entity, it is preferable to perform CT to confirm the diagnosis after performing US.

Completion appendectomy is the treatment of choice for stump appendicitis. In our case the surgeon decided to treat the patient with intravenous antibiotics, which followed with a good outcome.

\section{Learning points}

Stump appendicitis is a rare complication of postappendectomy.

- The diagnosis is made by imaging.

- Treatment of choice is surgical; however, conservative treatment can be successful.
To cite: Artul S, Daud M, Abboud N, et al. BMJ Case Rep Published online: [please include Day Month Yearl doi:10.1136/bcr-2014206775

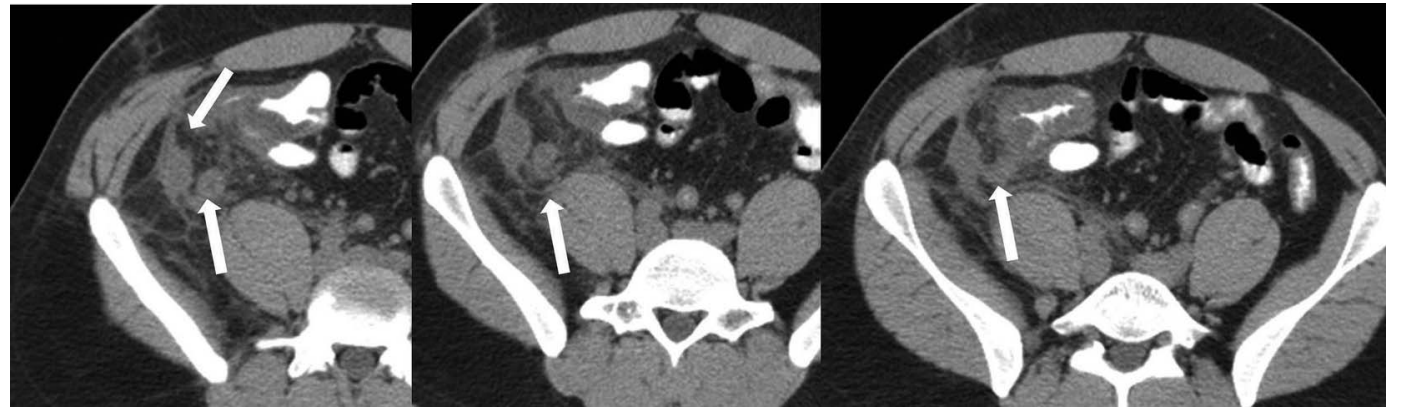

Figure 2 Abdominal serial axial ct slices at the level of the caecum showing thick inflamed stump of the appendix (white arrows). 
Competing interests None.

Patient consent Obtained.

Provenance and peer review Not commissioned; externally peer reviewed.

\section{REFERENCE}

1 Watkins BP, Kothari SN, Landercasper J. Stump appendicitis: case report and review. Surg Laprosc Endosc Percutan Tech 2004;2013:167-71.

Copyright 2014 BMJ Publishing Group. All rights reserved. For permission to reuse any of this content visit http://group.bmj.com/group/rights-licensing/permissions.

BMJ Case Report Fellows may re-use this article for personal use and teaching without any further permission.

Become a Fellow of BMJ Case Reports today and you can:

- Submit as many cases as you like

- Enjoy fast sympathetic peer review and rapid publication of accepted articles

- Access all the published articles

- Re-use any of the published material for personal use and teaching without further permission

For information on Institutional Fellowships contact consortiasales@bmjgroup.com

Visit casereports.bmj.com for more articles like this and to become a Fellow 